University for Business and Technology in Kosovo

UBT Knowledge Center

Nov 8th, 4:45 PM - 5:00 PM

\title{
Is there a European Innovation Crisis!? The impact of product and labour market deregulation
}

Armend Muja

University for Business and Technology, Armend.Muja@ubt-uni.net

Follow this and additional works at: https://knowledgecenter.ubt-uni.net/conference

Part of the Business Commons

\section{Recommended Citation}

Muja, Armend, "Is there a European Innovation Crisis!? The impact of product and labour market deregulation" (2014). UBT International Conference. 46.

https://knowledgecenter.ubt-uni.net/conference/2014/all-events/46

This Event is brought to you for free and open access by the Publication and Journals at UBT Knowledge Center. It has been accepted for inclusion in UBT International Conference by an authorized administrator of UBT Knowledge Center. For more information, please contact knowledge.center@ubt-uni.net. 


\title{
Is there a European Innovation Crisis!? The impact of product and labour market deregulation
}

\author{
Armend Muja \\ University for Business and Technology \\ Armend.Muja@ubt-uni.net
}

\begin{abstract}
Economists have often talked about the European Paradox:" - Europe having the necessary knowledge and research but failing to utilize these advantages and bring them to the markets. The perception, largely attributable to the media reporting, is that Europe lags behind the United States in innovation. While it is true that most of the e-commerce innovations were developed in the United States, Europe's economies did well over the 1990s despite the lack of major breakthroughs in hightech sphere. Thus, it is hard to say that Europe is facing an innovation crisis, and I will argue that Europe has other advantages that make it competitive globally. While Europe might not have as much success in innovation as the United States, it nevertheless, has been successful in more developed and mature segments of the markets. Moreover, I will argue that country's specialization depends on the setup of the institutions in the political economy. The countries utilize their comparative institutional advantage (CIA) to maintain competitive globally. Finally, I will argue against the idea of drastic deregulation of the product and labor markets in Europe. Doing so would be like shooting yourself in the foot since individual European countries would lose their comparative institutional advantage that allows them to stay competitive globally in the market for incremental innovation products.
\end{abstract}

Keywords:innovation crisis,labour market,EU

\section{Radical and incremental innovation}

First, I would like to introduce two terms, radical and incremental innovation, that will help us understand why Europe is not facing innovation crisis. The incremental innovation, present predominantly in Europe, implies continuous but small-scale improvements, also known as niches, to existing products (VOC, 39; Casper, 12). Incremental innovation matters most for maintaining competitiveness in the production of capital goods, such as machine tools and factory equipment, consumer household products, engines and specialized forms of transportation. Reputation and customer loyalty are of paramount importance in this market segment. Furthermore, incremental innovation is low risk and financing for it is usually provided by the banks (in Europe at least). Also, market leaders in incremental innovation are usually big multinational companies like Bosh and BMW in Germany or Renault or Peugeot in France.

Radical innovation implies "substantial shifts in product lines, the development of entirely new goods, or major changes to the production process" (VOC, 38). Radical innovation plays a crucial role in the rapidly changing sectors like biotechnology, software or semiconductors, which require innovative design and rapid product development based on research. In addition, rapid innovation also matters for the complex system-based products like telecommunications, defense systems, airlines, corporate finance and the likes (VOC, 39). Moreover, rapid innovation characterizes very high initial risk and greater chances of default. Hence, rapid innovation projects require access to financing schemes that would be willing to underwrite high-risk projects. Microsoft and Google would serve well as examples here. Predominant amount of companies that gained world-wide exposure and fame, like Google or Microsoft, are located in the United States and have done so through radical innovation. Moreover, their success received a lot of media coverage over the years as the new technology sparked interest among broad audiences. The hype associated with each IPO on the New York Stock Exchange reinforced in people's minds a perception that Europe is lagging behind the United States in innovation. 
No one was really mentioning, however, that when Europe was doing very well in mature markets like cars or engines, the American car industry was, and still is, struggling to remain competitive. While Microsoft's software changed the way offices operate in the 1990s, many well-established industries, shoe makers or car industry just to name a few, in the United States started to lose their competitive edge. The e-commerce hype did not have the same effect in Europe, where mature industries continued to improve their products and used new high-tech innovations to boost their productivity.

\section{Explaining innovation schemes in Europe and USA}

How then do we explain this difference in innovation schemes in Europe and the United States in the age of globalization (Soskice, 1999: 123)? A useful tool that could help explain Europe's preponderance in incremental innovation versus America's in rapid innovation is a framework of comparative institutional advantage (CIA), which states that some setups of institutions within political economy are more conducive to certain types of innovation. "Differing patterns of market regulation and business co-ordination have led to substantial differences in institutional frameworks' structuring activity in different areas of the economy" (Casper, 10). The coordinated market economies (CMEs), which characterize coordinated wage bargaining and highly skilled labor force, attract incremental innovation (Casper, et al., 9). Businesses in Germany, the most cited example of a CME, are usually large and are embedded within networks of powerful trade and industry associations, as well as, often legally mandated, labor and other interest groups organizations. Banking is the major source of financing, but banks usually finance capital investment rather than research (Casper, 12). Contracting is done through mediation between all the parties, which creates important non-market common good for the society. The legal systems in CMEs serve as guards of this system (Casper, 9-10). Even though this institutional setup might seem inflexible it supports incremental innovation well by securing skilled labor force that, due to guarantee of long term employment, autonomy from close monitoring and close inter-firm collaboration, undertakes innovation (VOC, 39).

The liberal market economies (LMEs) also referred to as the Anglo-Saxon models have flexible labor market where it is easy to hire and fire workers, unions are weak, contracting is very flexible and unrestricted by public institutions, emphasis is on the general knowledge rather than specific technical skills, equity markets pose few restrictions to investment or mergers and acquisitions, and innovation is mostly financed through the markets that are willing to underwrite high-risk projects in return for a possibility of very high return (VOC, 40). The high-tech innovation in the United States would not have been possible without a large capital market funding. Now that the differences between CMEs and LMEs were clearly laid out one can clearly see that CMEs specialize in the incremental innovation because that is where their comparative advantage lies. This fits well with the theory of comparative international trade, which states that "trade will not impoverish nations by driving their production abroad but enrich them by allowing each to specialize in the goods it produces most efficiently and exchange them for even more goods from other nations" (VOC, 36). Thus, CMEs utilize their national institutional advantage to specialize in incremental innovation because they can exchange their goods created through that form of innovation for more goods that require radical innovation. Consequently, the two markets, CMEs and LMEs, complement each other very well, and as long as there is free trade between these economies both sides will be better off from this specialization. Americans can sell European their software, whereas Europeans can sell Americans their top-notch cars and domestic appliances.

\section{Will deregulation foster innovation?}

The above point brings me to the second part of the question, whether drastic deregulation would help solve the innovation crisis in Europe. Since my argument states there is no innovation crisis in Europe 
I could simply leave it at that by saying that there is need for deregulation because there is no crisis to solve. Moreover, I could even bring up examples of Skype from Luxemburg or Finish Nokia and try to argue that there are economies within Europe that have created market conditions that are conducive to radical innovation, and they did not deviate much from CME setup. However, I would like to make a different point: Europe in order to stay competitive globally should constantly adjust national institutions to the changing world. I concur with David Soskice who argues that CMEs should not try to deregulate their economies but rather should foster re-regulation since it would preserve the longterm financial networks, cooperative skilled work forces, research networks and most importantly the comparative institutional advantage of CMEs (Soskice, 134). Government must strive to improve the business environment through ongoing dialog with companies (Porter, xxiv).

Moreover, I also think that CMEs could segment their labor markets into different categories and establish different set of rules for them. For example, there should be a different set of rules for large companies - the main drivers of incremental innovation - and a different set, and a lot more liberal with easier access to market funding for $R \& D$, for small and medium size businesses (SMEs). The idea is to preserve the institutional set up that is working well for incremental innovation, but at the same time to create more conducive environment for SMEs to boost Europe's participation in radical innovation and increase the importance of the service sector within the economy. Poland, for example, created a very rigid and protective labor market for the mining and other large industries, but at the same time relaxed the rules on hiring and firing for the rest of the enterprises especially for SMEs.

Europe, thanks to its national institutions of CMEs, is not facing innovation crisis. On the contrary, Europe's CME institutional setup beats the United States in incremental innovation in already established markets. Furthermore, the conclusion that I drew from analyzing the comparative institutional advantage within the framework of international trade theory is that Europe should not toy with drastic deregulation of this labor and product market because it would lose its comparative institutional advantage and its specialization in the incremental innovation. Instead, Europe should adapt its economies to constantly changing global markets through re-regulations and market segmentations.

\section{References}

1. Casper, Steven, Mark Lehrer, David Soskice. 1999. „Can High-Technology Industries Prosper in Germany? Institutional Frameworks and the Evolution of the German Software and Biotechnology Industries.” Industry and Innovation. Vol. 6. No 1, June 1999

2. Hall, Peter A, and David Soskice. 2001. "Varieties of Capitalism: The Institutional Foundations of Comparative Advantage." Varieties of Capitalism: The institutional foundations of competitiveness. Oxford: Oxford University Press: pp 36-44.

3. Porter, Michael. 1990. The Competitive Advantage of Nations. New York: The Free Press.

4. Soskice, David. 1999. "Divergent Production Regimes. Coordinated and Uncoordinated Market Economies in the 1980s and 1990s." in Continuity and Change in Contemporary Capitalism, edited by Herbert Kitschelt, Peter Lange, Gary Marks, and John D. Stephens. Cambridge: Cambridge University Press, pp. 101-134. 